\title{
Variability of Quantitative and Qualitative Characteristics of Fagus sylvatica 'Purpurea' Clones Produced by Grafting
}

\author{
Marina Ž. NONIĆ*, Dragana M. SKOČAJIĆ, Mihailo N. GRBIĆ, \\ Mirjana T. ŠIJAČIĆ-NIKOLIĆ
}

\author{
University of Belgrade, Faculty of Forestry, 1 Kneza Višslava, 11030, Belgrade, Serbia; marina.nonic@sfb.bg.ac.rs ( ${ }^{*}$ corresponding author); \\ dragana.skocajic@sfb.bg.ac.rs; mihailo.grbic@sfb.bg.ac.rs; mirjana.sijacic-nikolic@sfb.bg.ac.rs
}

\begin{abstract}
European beech is renowned due to its ornamental cultivars, such as purple beech (Fagus sylvatica 'Purpurea'), but its production in Serbia is represented in small number of nurseries. The aim of this paper was to analyze the success of heterovegetative propagation of purple beech and variability of different characteristics, in order to improve the production of nursery stocks for widespread use. The splice and wedge grafting were applied, using scions collected from five Fagus sylvatica 'Purpurea' adult trees, and two different rootstocks: five-year-old seedlings directly produced in nursery beds and one-year-old containerized seedlings. Analysis of grafting success rates, survival percentage, as well as quantitative (height and root collar diameter) and qualitative (leaf color) characteristics of produced grafts in four successive years, were investigated. Grafting performed using the containerized rootstocks showed the high success rate (50-80\%), but the survival percentage at the end of fourth year was lower (30-47\%). The survival percentage of grafts produced directly on rootstocks in nursery beds was $22-78 \%$ at the end of first year, and constantly kept those values in the next three years. The highest mean values of quantitative characteristics were found in clone number 5 and 1 , while the smallest were recorded in clone 3. Leaf color was intensive reddish-purple in most grafts, while in some grafts about $20 \%$ reddish-green leaves was recorded. Based on the obtained results, it can be stated that purple beech trees in Belgrade area could be used as mother plants and starting material for the improvement of its production.
\end{abstract}

Keywords: hetero-vegetative propagation, ornamental cultivars, purple beech, splice grafting, wedge grafting

\section{Introduction}

European beech (Fagus sylvatica L.) is, along with its significance as a forest species, renowned to its decorativeness and numerous ornamental cultivars, which are characterized by different color and shape of leaves, an atypical form of the crown, as well as different combinations of the aforementioned characteristics. A large number of ornamental European beech cultivars are planted in various green spaces worldwide, but a very small number of such trees have ascertained in Serbia. Only a few ornamental beech cultivars have been identified in the Belgrade area: Fagus sylvatica 'Pendula', Fagus sylvatica 'Purpurea', Fagus sylvatica 'Tricolor', Fagus sylvatica 'Purpurea Tricolor' and Fagus sylvatica 'Dawyck Purple', mostly in private gardens (Nonić, 2016).

The subject of this research was leaf-ornamental beech cultivar Fagus sylvatica 'Purpurea, which occurred three times spontaneously in Europe. It was firstly detected in 1680, in Switzerland, near the village Buch (canton of Zurich), where three trees were found (Wyman, 1962). A second time, before 1722, appeared in the nature in Germany (Hainleiter Forest, Thuringia), while the third time, natural mutant appeared in Italy (South Tyrol), around 1840 (Anon., 1894; Elwes, Henry, 1906; Lotsy, 1925). The leaves are similar in shape as in the basic type, dark purple, whereas the young leaves are dark red and change color to dark green, during the summer (Wyman, 1964; Hatch, 2007; Puschner and Brus, 2008).

For the time being, production of ornamental beech cultivars is represented in a very small number of nurseries in Serbia, with a negligible share of those plants in their total assortment (Nonić et al., 2016/c). Sometimes, declared properties of the cultivar are not clearly expressed in plants produced in nurseries, so there is a reasonable suspicion that those individuals actually present its generative offspring, or graftwoods for their production were taken from the generative propagated individuals. For those reasons, it was necessary to investigate the possibility of purple beech (Fagus sylvatica 'Purpurea') production by grafting. The purpose of this paper was to give certain recommendations for improvement of purple beech production in Serbia, based on the selection of parent trees and results of practical grafting. 
The vegetative plant propagation allows fixation of the combination of certain characteristics and is suitable for different ornamental cultivars (Đukić et al., 2006). An appropriate selection of starting material, based on the phenotypic manifestation of desirable characteristics, is very important. The selection of Fagus sylvatica 'Purpurea' adult trees in Serbia could be more suitable than a selection of starting material abroad, because such trees are well adapted to the local environmental conditions (Nonić, 2016) and could be used as scions sources for grafting and mass nursery production.

The previous studies of beech propagation were more prevalent in comparison to the studies related to the production of ornamental beech cultivars. In addition to the generative propagation, the different types of vegetative beech propagation have been applied in Serbia. Jovanović $(1966,1971)$ conducted the detailed study on heterovegetative and auto-vegetative propagation of Moesian beech and concluded that the propagation by cuttings was unsuccessful, while the good results were achieved by grafting and auto-vegetative propagation (Jovanović, 1971; Isajev, 2005). A possibility for successful in vitro tissue culture propagation of beech was ascertained, based on the research of Grbić (1988). Tucovic (1989-90) studied the vegetative incompatibility in the grafting of Moesian beech in Belgrade, where early incompatibility, as well as late mechanical, physiological and combined incompatibility were found. Tucović and Isajev (1996/97) were examining the causes of physiological compatibility-incompatibility in the grafting of trees.

De Vogel (1958) used three-year-old stocks of Fagus sylvatica for grafts of $F$. sylvatica 'Atropunicea' and concluded that grafts united satisfactorily in a cold frame, and treatment with an organic mercury compound prevented disease. Ramirez et al. (2006), grafted Fagus grandifolia Ehrh. rootstocks of unknown resistance to beech bark disease with scions collected from diseased trees and from those without symptoms of beech bark disease; grafting success varied between 12 and 30\%. HazubskaPrzybył et al. (2015) have studied the efficiency of induction of beech somatic embryogenesis and organogenesis from different types of explants, in different culture conditions, wherein they concluded that the induction of organogenesis from tested explants was more efficient than induction of somatic embryogenesis.

Previous studies on the ornamental beech cultivars were related to various topics: a description of cultivars (Wyman, 1964; Dönig, 1994; Tošić, 2005, 2006/a, 2006/b; Hatch, 2007; Puschner and Brus, 2008; Nonić et al., 2016/a), inheritance of leaf color in the generative progeny (Heinze, Geburek, 1995; Tošić, 2006/a), grafting of beech cultivars (Tošić, 2006/a; Cerar, 2010; Nonić et al., 2012/c, 2014/b, 2015; Nonić, 2016), analysis of morphological characteristics of buds (Nonić et al., 2014/a) and morphoanatomical characteristics of leaves (Vilotić et al., 2006; Čaňová et al., 2008; Nonić et al., 2012/a, 2012/b), as well as analysis of pigments in leaves (Hrkić Ilić et al., 2012; Nonić et al., 2016/b). However, until recently, detailed scientific research on vegetative propagation of ornamental beech cultivars in Serbia (Nonić, 2016) were missing.
The aim of this paper was to investigate the success of hetero-vegetative propagation of purple beech and analyze variability of quantitative and qualitative characteristics, in order to improve the production of nursery stocks for widespread use in Serbia.

\section{Materials and Methods}

\section{Plantmaterial}

The scion woods were collected from Fagus sylvatica 'Purpurea' adult trees, which were selected from two locations in Belgrade, based on qualitative characteristics of leaves. Considering the very small number of these trees, with satisfactory phenotypic characteristics, five parent trees were selected. The determination key for ornamental cultivars of European beech was used (Puschner and Brus, 2008), as well as description of the majority of beech cultivars (Wyman, 1964; Hatch, 2007). In addition to purple beech trees (trees number 1-5), one Moesian beech (tree number 6) was selected as control. Scions were collected during winter dormancy, from upper third of the crown and stored in the refrigerator until grafting (7-14 days). Different beech seedlings produced in the nursery, originating in Serbia, were used as rootstocks for grafting: five-year-old seedlings directly produced in the nursery bed and one-year-old containerized seedlings.

\section{Grafting}

The grafting was performed on April 6, 2011 in the nursery of the Faculty of Forestry in Belgrade, where the experimental fields were formed. The splice and wedge grafting methods were applied, according to protocols described by Tucović and Stilinović (1969); Grbić (2004); Hartmann et al. (2011); Isajev and Sijačić-Nikolić (2011); Kumar (2011). From the ratio of those grafts in which the activation of scion was recorded and the total number of grafted rootstocks, the grafting success percentage at the clone level was calculated. The grafting success rates were recorded four times during the growing season (June, August, September and October), to track changes and compare the values recorded at the beginning and the end of the growing season. The grafts survival percentage in four successive years (2011, 2012, 2013 and 2014) was recorded.

\section{Analysis of quantitative and qualitative characteristics}

An analysis of quantitative (height and root collar diameter) and qualitative (leaf color) characteristics of produced grafts in four successive years were investigated. The grafts height was measured from the substrate to the top of the scion, with an accuracy of $1 \mathrm{~mm}, 30$ days after grafting (the initial height). The grafts diameter was measured in the root collar zone, 30 days after grafting (the initial value of the root collar diameter), using a digital nonius, with an accuracy of $0.01 \mathrm{~mm}$. During the next three successive years, the measuring of the grafts height and the root collar diameter were done in the same way. The leaf color was observed at the clone level and presented as a ratio of grafts with reddish-purple and those with reddish-green leaves, from the total number of grafts.

The data were processed by the software packages Statgraphics Centurion XVI Version 16.1.11 and Statistica 
402

6.0. Standard statistical parameters (descriptive statistics) were presented. One-way analysis of variance (One-Way ANOVA) was used to evaluate the experimental data, followed by LSD test to detect significant differences ( $p \leq$ 0.05 ) between the mean values. Cluster analysis was applied using Single Linkage, Euclidean distances.

\section{Results and Discussion}

\section{Grafting success rates and grafts survival percentage}

The grafting success rates of plants produced by splice grafting using one-year-old containerized rootstocks (grafts type 1) and plants produced by wedge grafting using fiveyear-old rootstocks in nursery bed (grafts type 2) in first year are presented in Table 1.

Grafting performed using the containerized rootstocks (grafts type 1) showed the high success rate (> 55\% in average) during the first recording (Table 1). The highest average value (68.3\%) was recorded in August, while the percentage during the third (46.1\%) and fourth (44.9\%) recording was lower, due to the fact that a certain number of grafts did not survive until the end of the first vegetation period. The average grafting success rate of five purple beech clones, at the end of the first vegetation period, was slightly higher (45.32\%) compared to Moesian beech clone (43.3\%).

In the case of wedge grafting onto the five-year-old rootstocks, produced directly in nursery bed (grafts type 2 ), the average success rate during the first recording was lower (27.8\%), in comparison to the grafts type 1 . The rates were higher in the next three recording, with $57.4 \%$ at the end of the first vegetation period. This increase of grafting success during the summer months could be explained due to the fact that a certain number of scions with dormant buds were used, which were activated later and caused the subsequent formation of leaves.
The grafts survival percentage in four successive years is presented in Table 2. The highest survival percentage $(60.0 \%)$ of purple beech grafts produced onto the containerized rootstocks (grafts type 1) was recorded in clone number 5 , in 2011, and in clone number 4 (about $40.0 \%$ ), during the next three years. The survival percentage of Moesian beech grafts was constantly about $40.0 \%$. The survival percentage of grafts produced directly in the nursery bed (grafts type 2), ranged between 22.2-77.8\% (in average $57.4 \%$ ) at the end of first year, and constantly kept those values in the next three years (Table 2). The highest survival percentage $(77.8 \%)$, during all four years, was noted in clones number 1 and 4, while the lowest (22.2\%) was recorded in clone number 5 (in which the highest value was recorded after grafting performed using the containerized rootstocks).

Purple beech parent trees number 1 and 4 (ortets number 1 and 4) were adequate source of scions for wedge grafting of 5-year-old rootstocks in nursery bed, due to the constantly high survival percentage $(77.8 \%)$, which was recorded during the four successive years.

Those results are comparable to the results obtained in previous studies conducted on different beech species and cultivars. Grafting of four European beech cultivars: Fagus sylvatica 'Pendula', Fagus sylvatica 'Atropunicea', Fagus sylvatica 'Zlatia' and Fagus sylvatica 'Tricolor', has been performed in Slovenia, in order to determine the effect of different cultivars (scions' sources) on the grafting success (Cerar, 2010). The influence of rootstock thickness, as well as length and width of the scion on the grafting success, was investigated. There were no significant effect of those parameters on the grafting success, but it depended on the cultivar, from which the scions were collected. The highest grafting success rate was recorded when the scions from Fagus sylvatica 'Pendula' (80\%) and Fagus sylvatica 'Zlatia' (78\%) were used. The grafting success of cultivars Fagus

Table 1. The grafting success rates in first year

\begin{tabular}{|c|c|c|c|c|c|c|c|c|}
\hline \multirow{2}{*}{$\begin{array}{l}\text { Clone* } \\
\text { number }\end{array}$} & \multicolumn{4}{|c|}{ Grafting success rates in grafts type $1(\%)$} & \multicolumn{4}{|c|}{ Grafting success rates in grafts type $2(\%)$} \\
\hline & $13 / 06 / 2011$ & $10 / 08 / 2011$ & $15 / 09 / 2011$ & $20 / 10 / 2011$ & $13 / 06 / 2011$ & $10 / 08 / 2011$ & $15 / 09 / 2011$ & $20 / 10 / 2011$ \\
\hline 1 & 30.0 & 56.6 & 36.7 & 30.0 & 44.4 & 77.8 & 77.8 & 77.8 \\
\hline 2 & 70.0 & 73.3 & 36.7 & 33.3 & 44.4 & 55.6 & 66.7 & 66.7 \\
\hline 3 & 56.7 & 56.7 & 50.0 & 50.0 & 33.3 & 33.3 & 33.3 & 33.3 \\
\hline 4 & 70.0 & 76.7 & 53.3 & 53.3 & 33.3 & 55.6 & 66.7 & 77.8 \\
\hline 5 & 46.6 & 66.7 & 56.7 & 60.0 & 11.1 & 11.1 & 22.2 & 22.2 \\
\hline 6 & 63.3 & 80.0 & 43.3 & 43.3 & 0.0 & 55.6 & 66.7 & 66.7 \\
\hline Aver. & 56.1 & 68.3 & 46.1 & 44.9 & 27.8 & 48.1 & 55.6 & 57.4 \\
\hline
\end{tabular}

Legend: *a set of all ramets originating from the same ortet presents one clone; clones number 1-5: purple beech; clone number 6: Moesian beech (control); grafts type 1: plants produced by splice grafting using one-year-old containerized rootstocks; grafts type 2: plants produced by wedge grafting using five-year-old rootstocks in nursery bed

Table 2. The grafts survival percentage in four successive years

\begin{tabular}{|c|c|c|c|c|c|c|c|c|}
\hline \multirow{2}{*}{$\begin{array}{l}\text { Clone }^{*} \\
\text { number }\end{array}$} & \multicolumn{4}{|c|}{ Survival percentage of grafts type 1 (\%) } & \multicolumn{4}{|c|}{ Survival percentage of grafts type $2(\%)$} \\
\hline & 2011 & 2012 & 2013 & 2014 & 2011 & 2012 & 2013 & 2014 \\
\hline 1 & 30.0 & 30.0 & 30.0 & 30.0 & 77.8 & 77.8 & 77.8 & 77.8 \\
\hline 2 & 33.3 & 33.3 & 33.3 & 33.3 & 66.7 & 66.7 & 66.7 & 66.7 \\
\hline 3 & 50.0 & 46.6 & 43.3 & 43.3 & 33.3 & 33.3 & 33.3 & 33.3 \\
\hline 4 & 53.3 & 53.3 & 50.0 & 46.6 & 77.8 & 77.8 & 77.8 & 77.8 \\
\hline 5 & 60.0 & 46.6 & 33.3 & 33.3 & 22.2 & 22.2 & 22.2 & 22.2 \\
\hline 6 & 43.3 & 43.3 & 40.0 & 40.0 & 66.7 & 66.7 & 66.7 & 66.7 \\
\hline Average & 44.9 & 42.1 & 38.3 & 37.8 & 57.4 & 57.4 & 57.4 & 57.4 \\
\hline
\end{tabular}

Legend: ${ }^{*}$ a set of all ramets originating from the same ortet presents one clone; clones number 1-5: purple beech; clone number 6: Moesian beech (control); grafts type 1: plants produced by splice grafting using one-year-old containerized rootstocks; grafts type 2: plants produced by wedge grafting using five-year-old rootstocks in nursery bed 
sylvatica 'Atropunicea' was 50\%, which is in agreement with the results of the present study. The lowest success was noted for grafting the Fagus sylvatica 'Tricolor' scions (only $2 \%)$.

Unsuccessful grafting, in addition to the incorrect choice of scion's source, depends on callus formation during the graft union, technically incorrect graft, incompatibility between stock and scion, time of year or environmental factors, such as temperature and moisture, etc.

The success rate of Moesian beech grafting in Serbia was $>50 \%$, when the side grafting method was used, and $26 \%$ when wedge grafting method was used. The wedge grafting of Moesian beech performed in this study has shown better results (40.0-66.7\%).

Ramirez et al. (2006) performed the grafting of American beech (Fagus grandifolia Ehrh.), wherein the grafting survival percentage was about 30\% in 2003 and $12 \%$ in 2004 .

\section{Variability of quantitative and qualitative grafts characteristics}

The descriptive parameters of grafts height variability in four successive years are presented in Table 3 .

Based on the results of analysis of variance for the height of grafts type 2 , statistically significant differences $(p \leq 0.05)$ in all four years were found, while the differences in the height of grafts type 1 were significant only in 2013.

It can be stated that the average height of grafts type 2 were significantly higher compared to the height of grafts type 1. In April 2011, the mean height of grafts type 2 were in the range $220.56-494,44 \mathrm{~mm}$, while the values were slightly higher (294.44-645.56 mm) in 2012. In April 2013, a significant increase in the grafts heights was recorded, the mean value ranged up to $2050.00 \mathrm{~mm}$ in clone 5 , in which the highest mean value $(2200.00 \mathrm{~mm})$ was also recorded in April 2014.

The scion growth in the first year can be considered as one of the indicators of success callus bridge formation between the rootstocks and scions, but analysis in the next period indicate that increase in the first year " $i$ is not of crucial importance for the further grafts development"; in fact, in the second and subsequent years, the grafts development is directly conditioned by the individual traits of clones, which can manifest in grafts growth and increase of leaf area (Isajev, 2005).

The purple beech grafts type 1 and type 2 in 2011 and 2014 are shown in Fig. 1.

The heights of the grafts produced directly into the nursery bed, were several times higher in 2014, compared to the heights of the grafts produced onto the containerized rootstocks at the same time, as well as in 2011 (Fig. 1). This
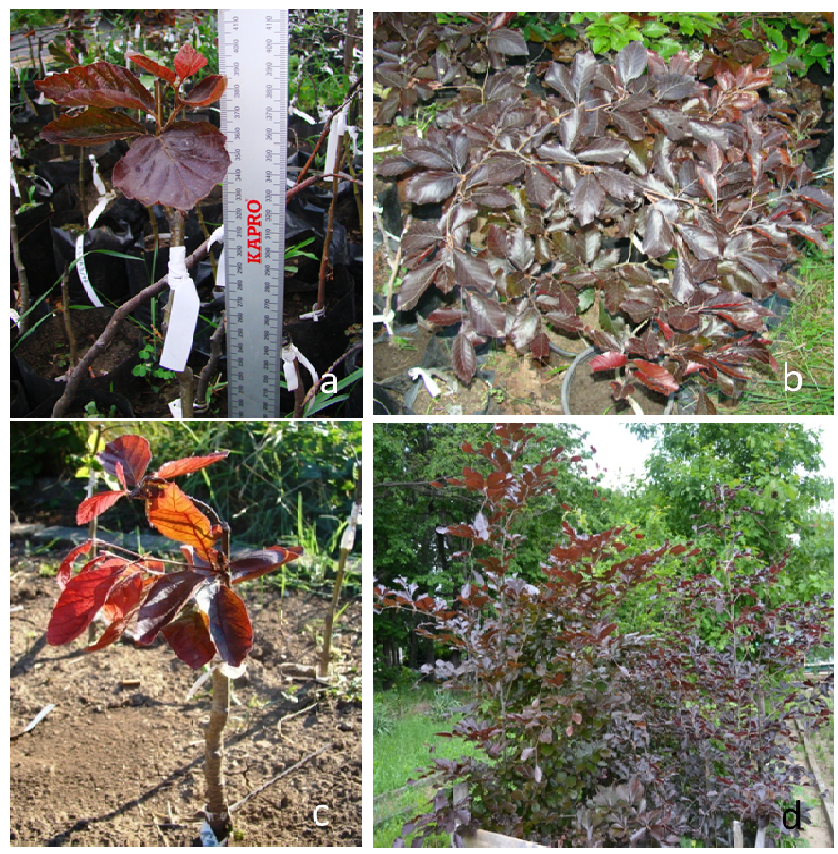

Fig. 1. Purple beech grafts type 1 and type 2 in 2011 and 2014. Grafts produced onto one-year-old containerized rootstocks 2011 (a); grafts produced onto one-year-old containerized rootstocks - 2014 (b); grafts produced onto five-year-old rootstocks in the nursery bed - 2011(c); grafts produced onto five-year-old rootstocks in nursery bed - 2014 (d)

Table 3. The descriptive parameters of grafts height variability in four successive years

\begin{tabular}{|c|c|c|c|c|c|c|c|c|}
\hline \multirow{3}{*}{$\mathrm{Cl}$. } & \multicolumn{8}{|c|}{ Heights of grafts type 1} \\
\hline & 2011 & 2012 & 2013 & 2014 & 2011 & 2012 & 2013 & 2014 \\
\hline & \multicolumn{4}{|c|}{ Mean \pm SD (in mm) } & \multicolumn{4}{|c|}{ Coefficient of variation (\%) } \\
\hline 1 & $146.7 \pm 24.5 \mathrm{ab}$ & $154.4 \pm 27.8 \mathrm{ab}$ & $385.5 \pm 134.5 \mathrm{ab}$ & $433.3 \pm 142.4 \mathrm{ab}$ & 16.7 & 18.0 & 34.9 & 32.9 \\
\hline 2 & $145.2 \pm 28.2 \mathrm{ab}$ & $153.3 \pm 27.8 \mathrm{ab}$ & $433.5 \pm 116.0 \mathrm{a}$ & $462.0 \pm 139.6 \mathrm{a}$ & 19.4 & 18.1 & 26.8 & 30.2 \\
\hline 3 & $138.2 \pm 28.4 b$ & $145.0 \pm 31.7 b$ & $309.5 \pm 128.0 \mathrm{c}$ & $360.7 \pm 131.6 b$ & 20.5 & 21.8 & 41.4 & 36.5 \\
\hline 4 & $139.5 \pm 23.8 \mathrm{~b}$ & $146.7 \pm 23.1 \mathrm{ab}$ & $391.5 \pm 110.1 \mathrm{ab}$ & $411.3 \pm 111.0 \mathrm{ab}$ & 17.1 & 15.8 & 28.1 & 26.9 \\
\hline 5 & $153.7 \pm 20.2 \mathrm{a}$ & $161.3 \pm 21.6 \mathrm{a}$ & $355.0 \pm 114.4 \mathrm{bc}$ & $376.7 \pm 118.9 \mathrm{ab}$ & 13.1 & 13.4 & 32.2 & 31.6 \\
\hline \multirow[t]{2}{*}{6} & $153.2 \pm 20.0 \mathrm{a}$ & $160.6 \pm 21.9 \mathrm{a}$ & $335.0 \pm 81.1 \mathrm{bc}$ & $356.3 \pm 78.9 \mathrm{~b}$ & 13.1 & 13.6 & 24.2 & 31.3 \\
\hline & \multicolumn{8}{|c|}{ Heights of grafts type 2} \\
\hline \multirow[t]{2}{*}{$\mathrm{Cl}$. } & 2011 & 2012 & 2013 & 2014 & 2011 & 2012 & 2013 & 2014 \\
\hline & \multicolumn{4}{|c|}{ Mean \pm SD (in mm) } & \multicolumn{4}{|c|}{ Coefficient of variation (\%) } \\
\hline 1 & $438.3 \pm 152.2 \mathrm{ab}$ & $645.6 \pm 243.3 \mathrm{a}$ & $1446.7 \pm 519.0 \mathrm{~b}$ & $1690.0 \pm 527.3 \mathrm{~b}$ & 34.7 & 37.7 & 35.4 & 31.2 \\
\hline 2 & $324.4 \pm 63.7 \mathrm{bc}$ & $438.9 \pm 160.2 \mathrm{ab}$ & $1318.9 \pm 279.6 \mathrm{bc}$ & $1502.2 \pm 291.3 b$ & 19.6 & 36.5 & 21.2 & 19.4 \\
\hline 3 & $220.5 \pm 78.9 c$ & $642.2 \pm 339.3 \mathrm{a}$ & $970.0 \pm 486.6 \mathrm{c}$ & $1296.7 \pm 361.8 b$ & 35.8 & 52.8 & 50.2 & 27.9 \\
\hline 4 & $332.2 \pm 177.3 b c$ & $486.1 \pm 285.6 \mathrm{ab}$ & $1326.7 \pm 603.8 b c$ & $1473.3 \pm 616.0 \mathrm{~b}$ & 53.4 & 58.8 & 45.5 & 41.8 \\
\hline 5 & $236.1 \pm 105.7 c$ & $294.4 \pm 224.1 \mathrm{~b}$ & $2050.0 \pm 474.3 \mathrm{a}$ & $2200.0 \pm 474.3 \mathrm{a}$ & 44.7 & 76.1 & 23.1 & 21.6 \\
\hline 6 & $494.4 \pm 146.0 \mathrm{a}$ & $645.6 \pm 289.2 \mathrm{a}$ & $1338.9 \pm 324.3 \mathrm{bc}$ & $1477.8 \pm 353.9 \mathrm{~b}$ & 29.5 & 44.8 & 24.2 & 23.9 \\
\hline
\end{tabular}

Note: the data were showed as means \pm SD which were compared by LSD test $(\mathrm{p} \leq 0.05) ;{ }^{a}$ Different letters in the same column denote a significant difference according to LSD test, $\mathrm{p} \leq 0.05$

Legend: clones number 1-5: purple beech; clone number 6: Moesian beech (control); grafts type 1: plants produced by splice grafting using one-year-old containerized rootstocks; grafts type 2: plants produced by wedge grafting using five-year-old rootstocks in nursery bed 
404

result points to the great importance of planned production of high-quality rootstocks, which should be grafted directly into the nursery bed.

Based on the dendrogram of cluster analysis (Fig. 2), it can be seen that the grafts of the clone 5 were at the largest distance from the other grafts. At the smallest distance were grouped clones number 2 and 4 which form a homogeneous group with the clones 1 and 4 . Clone number 3 is grouped with other clones at a greater distance.

The descriptive parameters of root collar diameter variability of grafts type 1 and type 2 , in four successive years, are presented in Table 4. Based on the results of analysis of variance for the root collar diameter of grafts type 1 , statistically significant differences $(p \leq 0.05)$ in third and fourth year were found, while the differences in the first and second year after grafting were not significant. In the case of grafts type 2, only in 2011 the differences were not statistically significant $(\mathrm{p}>0.05)$. This result can be

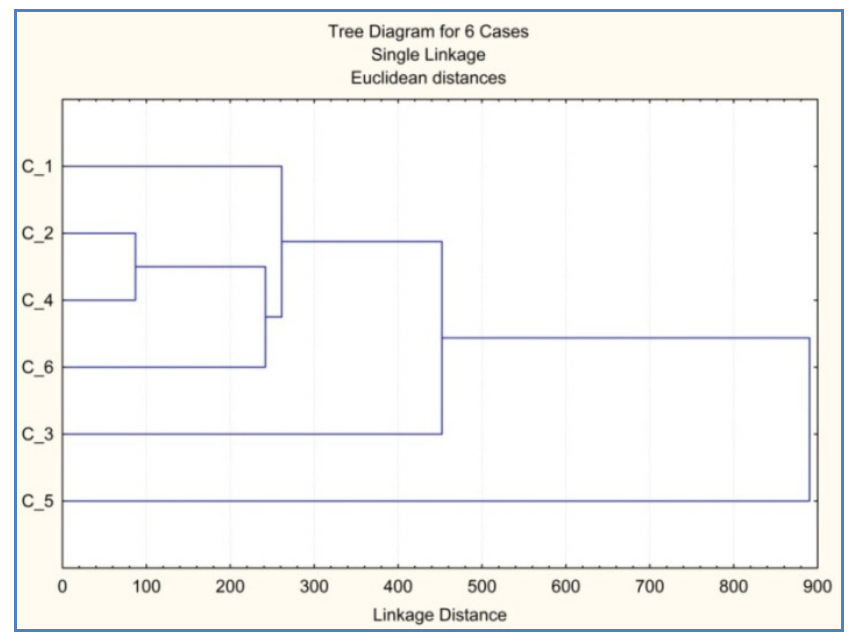

Fig. 2. Dendrogram obtained by cluster analysis on the heights of grafts type 1 and 2 explained by the fact that the value of this property in the first growing season, actually presents the root collar diameter of rootstock and the parent tree (an ortet), from which the scion woods were collected, should not have a major impact on the root collar diameter. The result was expected, since the rootstocks were of the same origin and age (one-year-old in grafts type 1 and 5-year-old in grafts type 2) and grown in identical environmental conditions.

The significant changes in the root collar diameter values were found between the second (2012) and third (2013) year after grafting, when the grafts began to grow more intense; in April 2013 and 2014, the highest average diameter was found in clone number 5 .

Based on the dendrogram of cluster analysis (Fig. 3), it can be stated that the grafts of the clone 5 were at the largest distance from the other grafts, the same as in Fig. 3. At the smallest distance were grouped clones number 2 and 3 which form a homogeneous group with the clone 4 .

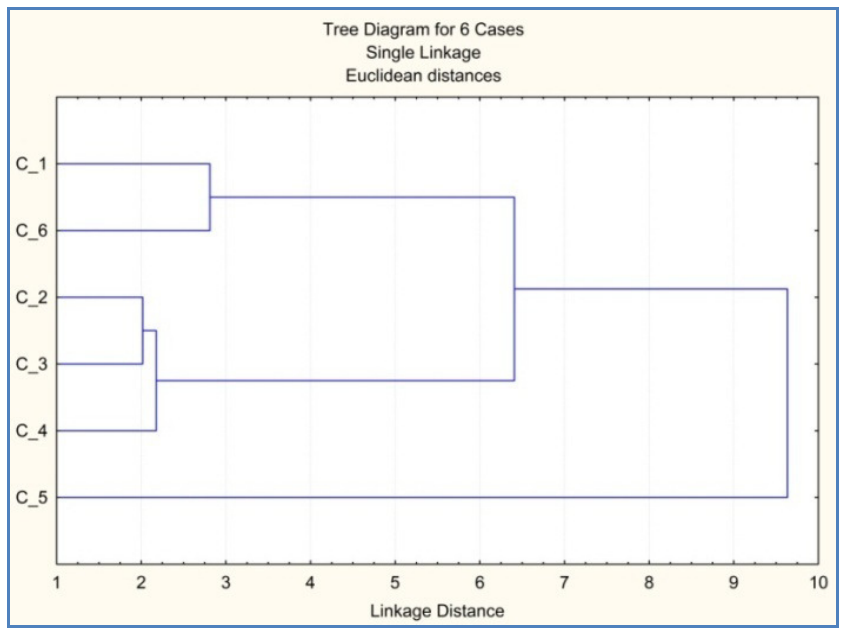

Fig. 3. Dendrogram obtained by cluster analysis on the root collar diameters of grafts type 1 and 2

Table 4. The descriptive parameters of root collar diameter variability in four successive years

\begin{tabular}{|c|c|c|c|c|c|c|c|c|}
\hline \multirow{3}{*}{ Clone } & \multicolumn{8}{|c|}{ Root collar diameter of grafts type 1} \\
\hline & 2011 & 2012 & 2013 & 2014 & 2011 & 2012 & 2013 & 2014 \\
\hline & \multicolumn{4}{|c|}{ Mean \pm SD (in mm) } & \multicolumn{4}{|c|}{ Coefficient of variation (\%) } \\
\hline 1 & $8.5 \pm 1.5 \mathrm{a}$ & $9.09 \pm 1.5 \mathrm{a}$ & $10.5 \pm 2.3 \mathrm{~b}$ & $11.7 \pm 1.9 \mathrm{ab}$ & 17.4 & 16.2 & 21.8 & 16.6 \\
\hline 2 & $8.3 \pm 1.7 \mathrm{ab}$ & $8.8 \pm 1.8 \mathrm{a}$ & $9.5 \pm 1.7 \mathrm{~b}$ & $10.3 \pm 2.0 \mathrm{~b}$ & 20.1 & 19.9 & 18.2 & 19.5 \\
\hline 3 & $7.9 \pm 1.7 \mathrm{ab}$ & $8.5 \pm 1.9 \mathrm{a}$ & $9.7 \pm 1.7 \mathrm{~b}$ & $10.7 \pm 1.9 \mathrm{~b}$ & 21.3 & 23.1 & 17.0 & 18.6 \\
\hline 4 & $7.7 \pm 1.6 b$ & $8.6 \pm 1.8 \mathrm{a}$ & $9.4 \pm 2.1 \mathrm{~b}$ & $10.8 \pm 2.8 \mathrm{~b}$ & 20.9 & 21.2 & 22.2 & 25.6 \\
\hline 5 & $7.8 \pm 1.4 \mathrm{ab}$ & $8.3 \pm 1.3 \mathrm{a}$ & $10.0 \pm 2.5 b$ & $10.7 \pm 2.6 b$ & 18.1 & 15.7 & 24.7 & 23.9 \\
\hline \multirow[t]{2}{*}{6} & $7.8 \pm 1.4 \mathrm{ab}$ & $8.4 \pm 1.7 \mathrm{a}$ & $12.1 \pm 2.6 \mathrm{a}$ & $13.2 \pm 2.9 \mathrm{a}$ & 18.4 & 19.7 & 21.7 & 21.7 \\
\hline & \multicolumn{8}{|c|}{ Root collar diameter of grafts type 2} \\
\hline \multirow[t]{2}{*}{ Clone } & 2011 & 2012 & 2013 & 2014 & 2011 & 2012 & 2013 & 2014 \\
\hline & \multicolumn{4}{|c|}{ Mean \pm SD (in mm) } & \multicolumn{4}{|c|}{ Coefficient of variation (\%) } \\
\hline 1 & $10.0 \pm 3.3 \mathrm{a}$ & $12.8 \pm 3.6 \mathrm{a}$ & $20.0 \pm 6.1 \mathrm{~b}$ & $23.1 \pm 4.7 b c$ & 32.5 & 27.8 & 30.6 & 20.5 \\
\hline 2 & $9.7 \pm 2.5 \mathrm{a}$ & $10.8 \pm 2.7 \mathrm{ab}$ & $14.6 \pm 3.4 b$ & $17.9 \pm 2.5 \mathrm{~d}$ & 25.9 & 24.6 & 23.8 & 13.9 \\
\hline 3 & $8.2 \pm 1.9 \mathrm{a}$ & $10.1 \pm 0.7 \mathrm{ab}$ & $14.6 \pm 3.6 b$ & $16.9 \pm 4.4 \mathrm{~d}$ & 23.4 & 7.3 & 24.9 & 25.6 \\
\hline 4 & $10.7 \pm 2.4 \mathrm{a}$ & $11.61 \pm 4.1 \mathrm{a}$ & $15.9 \pm 4.1 \mathrm{~b}$ & $18.7 \pm 4.5 \mathrm{~cd}$ & 22.2 & 34.9 & 25.8 & 24.3 \\
\hline 5 & $8.9 \pm 3.5 \mathrm{a}$ & $8.0 \pm 3.3 b$ & $26.6 \pm 6.5 \mathrm{a}$ & $29.5 \pm 6.6 \mathrm{a}$ & 39.5 & 40.8 & 24.3 & 22.5 \\
\hline 6 & $9.8 \pm 1.9 \mathrm{a}$ & $11.9 \pm 2.5 \mathrm{a}$ & $20.6 \pm 9.7 b$ & $24.0 \pm 5.4 b$ & 19.4 & 20.9 & 59.5 & 22.3 \\
\hline
\end{tabular}

Note: the data were showed as means \pm SD which were compared by LSD test $(\mathrm{p} \leq 0.05) ;{ }^{2}$ Different letters in the same column denote a significant difference according to LSD test, $\mathrm{p} \leq 0.05$

Legend: clones number 1-5: purple beech; clone number 6: Moesian beech (control); grafts type 1: plants produced by splice grafting using one-year-old containerized rootstocks; grafts type 2: plants produced by wedge grafting using five-year-old rootstocks in nursery bed 
Table 5. Qualitative characteristics of grafts type 1 and type 2 - leaf color (\%)

\begin{tabular}{cccc}
\hline Clone & $\begin{array}{c}\text { Reddish-purple } \\
\text { leaves }\end{array}$ & $\begin{array}{c}\text { Reddish-green } \\
\text { leaves }\end{array}$ & $\begin{array}{c}\text { Green } \\
\text { leaves }\end{array}$ \\
\hline 1 & 56 & 44 & 0 \\
2 & 70 & 30 & 0 \\
3 & 75 & 25 & 0 \\
4 & 92 & 8 & 0 \\
5 & 67 & 33 & 0 \\
6 & 0 & 0 & 100 \\
\hline
\end{tabular}

Ramirez et al. (2006) who grafted Fagus grandifolia Ehrh., concluded that rootstocks with higher root collar diameter values, significantly affected the increase of grafting success. The higher mean values of quantitative characteristics (grafts height and root collar diameter) in this study were mainly found in clones number 5 and 1 , while the smallest were recorded in clone 3 .

The qualitative characteristics of grafts type 1 and type 2 (at the level of all clones) are presented in Table 5. Leaf color was intensive reddish-purple in most grafts. The vegetative propagation allows production of copies (clones) that have the same characteristics as the parent plant, but the influence of the environmental factors may cause the appearance of different phenotypes of genetically identical plants. In clone $1>40 \%$ reddish-green leaves were recorded, mainly in those plants that were grown in shadow. Moesian beech leaves (clone 6), were green, as expected. Heinze, Geburek (1995) presented the results of the analysis of DNA markers, concerning the gene responsible for the leaf color in purple beech, wherein the generative propagation of this cultivar was done. The segregation of phenotypes in the offspring was 1:1 (500 seedlings with red leaves and 509 seedlings with green leaves). Tošić (2005; 2006/a, 2006/b) wrote detailed about the beech cultivar with yellow leaves (Fagus sylvatica 'Luteofolia' and a new variety of Fagus moesiaca (K. Maly) Czecz., with golden-yellow leaves. Tošić (2006/a) stated that by generative propagation of yellowleafed beech tree, the offspring in a large percentage inherits yellow leaves.

\section{Conclusions}

Based on the obtained results, it can be stated that purple beech trees grown in Belgrade area could be used as a starting plant material for improvement of the purple beech nursery stocks production for widespread use in Serbia. Conducted research confirms the importance of appropriate choice of grafting components, which is, along with their genetic similarity and time of grafting, an essential precondition for the successful production of European beech cultivars. Grafting of purple beech scions onto the rootstocks directly produced in the nursery bed showed the best average results.

\section{Acknowledgements}

The research was financed by the project: "Establishment of forest plantations to increase the afforested areas in Serbia" (TR 31041), Ministry of Education and Science of the Republic of Serbia.

\section{References}

Anonymus (1894). The origin of the Purple beech. Garden and Forest 306(7) (an electronic version). The Garden and Forest Publishing Co:2-3.

Cerar T (2010). Cepljenje različnih sort navadne bukve (Fagus sylvatica L.) [Grafting of different European beech (Fagus sylvatica L.) cultivars]. Dipl. delo, Univerza v Mariboru - Fakulteta za kmetijstvo in biosistemske vede, Maribor (51).

Čaňová I, Ďurkovič J, Hladká D (2008). Stomatal and chlorophyll fluorescence characteristics in European beech cultivars during leaf development. Biologia Plantarum 52(3):577-581.

De Vogel P (1958). Het enten van beuken onder glas [Grafting beech under glass]. In: Jaarboek. Proefstation voor de Boomwekerij te Boskoop [Annualbook. Research station for nursery Boskoop] pp 43-44.

Dönig G (1994). Die Park- und Gartenformen der Rotbuche - Fagus sylvatica $\mathrm{L}$. [The park and garden forms of the red beech - Fagus sylvatica L.]. Rinteln, Gartenbild Heinz Hansmann (286).

Đukić M, Grbić M, Skočajić D, Đunisijević D (2006). Spontane promene kao osnova za dobijanje novih kultivara ukrasnih sadnica [Spontaneous changes a basis for new ornamental woody plant cultivars]. Glasnik Šumarskog fakulteta 93, Univerzitet u Beogradu - Šumarski fakultet, Beograd:71-81.

Elwes HJ, Henry A (1906). The trees of Great Britain and Ireland Volume 1, Edinburgh: Privately Printed:6-23

Grbić M (1988): Razmnožavanje bukve (Fagus moesiaca (Maly) Czeczott.) i kitnjaka (Quercus sessilis Ehrh.) in vitro kao osnove za intenziviranje naučnoistraživačkog rada i proizvodnje sadnica željenih osobina [Propagation of beech (Fagus moesiaca (Maly) Czeczott.) and oak (Quercus sessilis Ehrh.) in vitro as a basis for the intensification of scientific research and the production of plants with the desired properties]. In: Propadanje šumskih ekosistema uzroci, posledice i mere (II sveska), Igman pp 104-108.

Grbić M (2004). Vegetativno razmnožavanje ukrasnog drveća ižbunja [Vegetative propagation of ornamental trees and shrubs]. Ne \& Bo Tragovi, Beograd (488).

Hartmann H, Kester D, Davies F, Geneve R (2011). Hartmann \& Kester's Plant Propagation: Principles and Practices (8th Edition). Pearson Education, Inc., Publishing as Prentice Hall pp 415-509.

Hatch L (2007). Cultivars of Woody Plants, Volume I: A-G. TCR Press, Raleigh. Digital PDF e Book pp 906-927.

Hazubska-Przybył T, Chmielarz P, Bojarczuk K (2015). In vitro responses of various explants of Fagus sylvatica. Dendrobiology 73:135-144.

Heinze B, Geburek T (1995). Searching for DNA Markers Linked to Leaf Colour in Copper Beech, Fagus sylvatica L. var. Atropunicea. Silvae Genetica 44(5-6):339-343.

Hrkić Ilić Z, Oljača R, Šumatić N, Kapović M, Bodružić M (2012). Concentration of pigments in the leaves of yellow beech (Fagus moesiaca (K. Maly) Czecz. var. aurea serbica Tošić) in the vicinity of Kotor Varoš in Republic of Srpska. Proceedings of International Scientific Conference - Forestry science and practice 
406

for the purpose of sustainable development of forestry. Banja Luka, Bosnia and Herzegovina pp 299-307.

Isajev V (2005). Varijabilitet i oplemenjivanje bukve u Srbiji [Variability and breeding of beech in Serbia]. In: Stojanović $\mathrm{Lj}$ (Ed). Bukva (Fagus moesiaca /Domin, Mally/ Czeczott.) u Srbiji [Beech (Fagus moesiaca /Domin, Mally/ Czeczott.) in Serbia]. Udruženje šumarskih inženjera i tehničara Srbije, Beograd i Šumarski fakultet Univerziteta u Beogradu, Beograd pp 139-176.

Isajev V, Šijačić-Nikolić M (2011). Praktikum iz genetike sa oplemenjivanjem biljaka [Practicum in genetics with plant breeding]. Šumarski fakultet, Univerziteta u Beogradu, Beograd (241).

Jovanović M (1966). Prilog proučavanju vegetativnog razmnožavanja bukve Fagus moesiaca (Domin, Maly) Czeczott. [Contribution to the study of vegetative propagation of beech Fagus moesiaca (Domin, Maly) Czeczott.]. Magistarski rad u rukopisu [Master Thesis], Univerzitet u Beogradu - Šumarski fakultet, Beograd (76).

Jovanović M (1971). Oplemenjivanje bukve (Fagus moesiaca (Domin, Maly) Czeczott.) u SR. Srbiji [Breeding of beech Fagus moesiaca (Domin, Maly) Czeczott. In Serbia]. Doktorska disertacija u rukopisu [PhD Thesis], Univerzitet u Beogradu - Šumarski fakultet, Beograd.

Kumar GNM (2011). Propagation of Plants by Grafting and Budding. A Pacific Northwesr extension publication PNW496. Washington State University, Oregon State University, University of Idaho pp 1-18.

Lotsy JP (1925). On the origin of red-leaved forms in a cross of Nothofagus fusca $\times$ Cliffortioides. Genetica 7(3-4):241-252.

Nonić M, Jokanović D, Knežević R (2012/a). Comparative research of size and number of stomata of different beech cultivars. In: CD ROM Proceedings from International Scientific Conference „Forests in Future - Sustainable Use, Risks and Challenges“, Institute of Forestry, Belgrade, pp 179-185.

Nonić M, Knežević R, Šijačić-Nikolić M (2012/b). Morfometrijske karakteristike listova različitih kultivara Evropske bukve (Fagus sylvatica L.) i mezijske bukve (Fagus moesiaca (Domin, Maly) Czeczott.) Morphometric characteristics of leaves of different European beech (Fagus sylvatica L.) cultivars and Moesian beech (Fagus moesiaca (Domin, Maly) Czeczott.), Šumarstvo 2012(1-2), Beograd:107-119.

Nonić M, Šijačić-Nikolić M, Knežević R (2012/c). Analysis of survival and vitality of beech plants grafted by method of splice grafting. In: CD ROM Proceedings from International Scientific Conference "Forests in Future - Sustainable Use, Risks and Challenges". Institute of Forestry, Belgrade pp 425-432.

Nonić M, Devetaković J, Ivetić V, Šijačić-Nikolić M (2014/a). Morphometric characteristics of buds of different European beech cultivars. Book of abstracts of the 2014 IUFRO Forest Tree Breeding Conference. Prague, Czech Republic p 73.

Nonić M, Grbić M, Šijačić-Nikolić M (2014/b). Analysis of grafting success in production of ornamental beech cultivars. Book of abstracts of V Congress of the Serbian Genetic Society. Kladovo -
Belgrade, Serbiap 334.

Nonić M, Šijačić-Nikolić M, Grbić M, Vilotić D (2015). Nursery production of purple beech (Fagus sylvatica 'Purpurea') by grafting. Book of abstracts of the $2^{\text {nd }}$ International Conference on Plant Biology and $21^{\text {th }}$ Symposium of the Serbian Plant Physiology Society. Petnica Science Center, Serbia p 27.

Nonić M (2016). Unapredenje masovne proizvodnje lisno-dekorativnih kultivara bukve kalemljenjem. [Improving mass production of leafornamental beech cultivars by grafting], Doktorska disertacija u rukopisu $[\mathrm{PhD}$ Thesis], Univerzitet u Beogradu-Šumarski fakultet, Beograd.

Nonić M, Popović V, Grbić M, Devetaković J, Šjačić-Nikolić M (2016/a). Ukrasni kultivari kao osnova za dalje oplemenjivanje bukve na dekorativna svojstva [Ornamental cultivars as a basis for further beech breeding for ornamental characteristics], Knjiga apstrakata, V Simpozijum Sekcije za oplemenjivanje organizama Društva genetičara Srbije, Kladovo pp 128-129.

Nonić M, Popović V, Šijačić-Nikolić M, Mataruga M, Cvjetković B, Daničić V (2016/b). Varijabilnost sadržaja fotosintetičkih pigmenata različitih lisno-dekorativnih kultivara bukve, [Variability of photosynthetic pigments content in different leafornamental beech cultivars], Knjiga apstrakata, V Simpozijum Sekcije za oplemenjivanje organizama Društva genetičara Srbije. Kladovo pp 138-139.

Nonić M, Nedeljković J, Nonić D, Šijačić-Nikolić M (2016/c). Attitudes of ornamental trees and shrubs producers towards nursery production of ornamental beech cultivars in Serbia. Bulletin of the Faculty of Forestry 20'16, Issue 114, University of Belgrade - Faculty of Forestry, Belgrade:137-168.

Puschner M, Brus R (2008). Okrasne sorte bukve (Fagus sylvatica L.) v Sloveniji [Ornamental cultivars of European beech (Fagus sylvatica L.) in Slovenia]. Gozdarski Vestnik 66(2), Zveza gozdarskih društev Slovenije, Ljubljana:121-129.

Ramirez M, Loo J, Krasowski MJ (2006). Evaluation of resistance to the Beech scale insect (Cryptococcus fagisuga) and propagation of American beech (Fagus grandifolia) by grafting. Silvae Genetica 56(3-4):163-169.

Tošić M (2005). Novi varijetet bukve Fagus moesiaca (K. Mally) Czecz. sa zlatno-žutim lišćem [The new variety of beech Fagus moesiaca (K. Mally) Czecz. with golden-yellow leaves]. Zbornik radova VIII Simpozijuma o flori jugoistočne Srbije i susednih regiona, Niš pp 135-141.

Tošić M (2006/a). Bukva sa žutim lišćem u Republici Srpskoj, značajna prirodna retkost [Beech with yellow leaves in the Republic of Serbian, significant natural rarity]. Glasnik Šumarskog fakulteta Univerziteta u Banjoj Luci 5, Univerzitetu Banjoj Luci Šumarski fakultet, Banja Luka:23-35.

Tošić M (2006/b). Novi dekorativni kultivar žutolisne bukve (Fagus silvatica L. 'Luteofolia') [New ornamental cultivar of yellow-leaf beech (Fagus silvatica L. 'Luteofolia')]. Zbornik abstrakata trećeg simpozijuma selekcije za oplemenjivanje organizama Društva genetičara Srbije, Zlatibor p 112. 
Tucović A, Stilinović S (1969). Kalemljenje sumskkog i ukrasnog drveća i žbunja [Grafting of forest and ornamental trees and shrubs]. Jugoslovenski poljoprivredno-šumarski centar-Služba šumske proizvodnje, Beograd (68).

Tucović A (1989/1990). Savladivanje vegetativne inkompatibilnosti pri kalemljenju mezijske bukve - Fagus moesiaca (Domin, Maly) Czezott. [Overcoming of vegetative incompatibility in grafting of Moesian beech Fagus moesiaca (Domin, Maly) Czezott.]. Glasnik Šumarskog fakulteta 71-72:217-225.

Tucović A, Isajev V (1996/97). Uzroci fiziološke kompatibilnosti inkompatibilnosti pri kalemljenju drveća [The causes of physiological compatibility - incompatibility in grafting trees]. Glasnik Šumarskog fakulteta 78-79:43-54.
Vilotić D, Tošić M, Radošević G (2006). Morpho-anatomic characters of the leaves of yellow-leaf and red-leaf beech cultivars. Proceedings of the IUFRO Division 2 Joint Conference: Low Input Breeding and Conservation of Forest Genetic Resources. Antalya pp 36-40.

Wyman D (1962). The majestic beeches. Arnoldia - a continuation of the Bulletin of popular information of the Arnold Arboretum 22(1). Harvard University:1-7.

Wyman D (1964). Registration list of cultivar names of Fagus L. Arnoldia - a continuation of the Bulletin of popular information of the Arnold Arboretum 24(1). Harvard University, Cambrige:1-8. 